RADIATION NATION 



\title{
Radiation Nation
}

THREE MILE ISLAND AND THE POLITICAL TRANSFORMATION OF THE $1970 \mathrm{~s}$

Natasha Zaretsky

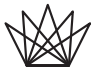 \\ Columbia University Press \\ New York
}


Columbia University Press

Publishers Since 1893

New York Chichester, West Sussex

cup.columbia.edu

Copyright (c) 2018 Columbia University Press

All rights reserved

Library of Congress Cataloging-in-Publication Data

Names: Zaretsky, Natasha, 1970- author.

Title: Radiation nation: Three Mile Island and the political transformation of the 1970s / Natasha Zaretsky.

Other titles: Three Mile Island and the political transformation of the 1970 s

Description: New York: Columbia University Press, [2018] | Includes bibliographical references and index.

Identifiers: LCCN 2017038412 | ISBN 9780231179812 (pbk.: alk. paper) |

ISBN 9780231179805 (cloth: alk. paper)

Subjects: LCSH: United States-Politics and government-1977-1981. | Nuclear power plants-Accidents-Pennsylvania-Harrisburg Region. | Three Mile Island Nuclear Power Plant (Pa.) - Accidents-Social aspects. | Radiation injuries-United States-Social aspects. |

Political ecology-United States-History-2oth century. | Nationalism-United States-

History-2oth century. | Conservatism-Environmental aspects-United States.

Classification: LCC E872 .Z37 2018 | DDC 363.17990974818-dc23

LC record available at https://lccn.loc.gov/2017038412

Columbia University Press books are printed on permanent and durable acid-free paper.

Printed in the United States of America

Cover image: ๑ AP Photo/Harrisburg Patriot-News, Martha Cooper 
For Jonathan 

The accident had ruined a lot of lives. Or, to be exact, it had busted apart the structures on which those lives had dependeddepended, I guess, to a greater degree than we had originally believed. A town needs its children for a lot more than it thinks.

-Russell Banks, The Sweet Hereafter 
